\title{
Introduction: Natural resources and ethnic conflicts in Asia Pacific
}

\author{
Jefferson Fox* and Arun Swamy† \\ *East-West Center, 1601 East-West Road, Honolulu, HI 96848, USA. \\ Email: foxj@eastwestcenter.org \\ †785 Termino Ave., Long Beach, CA 90804, USA. \\ Email: arswamy@gmail.com
}

\begin{abstract}
The papers in this special issue are the product of a comparative interdisciplinary workshop on 'Natural Resources and Violent Ethnic Conflicts in the Asia Pacific Region' held in Honolulu, Hawaii, 18-20 March 2005. The workshop brought together scholars who study conflicts between ethnic groups and those who study conflicts over natural resource claims in order to examine the interplay of resources and ethnicity and to seek answers to the question of why violence occurs in some cases and not in others. Both sets of scholars agreed on some points but disagreed on others. They agreed that ethnic and resource grievances occur not so much out of objective deprivation but out of 'relative deprivation' when groups compare their situation with others, to the past, or to future expectations. They both stressed the role of democratic processes in alleviating resource competition and ethnic conflicts - but they did this in different ways. The perspectives and solutions offered by these papers sum to a deeper and more contextualised understanding of the cause of conflict and to mutually reinforcing solutions for resolving them.
\end{abstract}

Keywords: Asia Pacific, ethnic conflict, natural resources, political ecology, political ethnology

Asia recently surpassed Africa in the number of new armed conflicts (USAID, 2006). Possible explanations for these conflicts proffered by different kinds of scholars range from failures related to natural resource management, through a variety of failures in economic policy to the suppression of ethnic groups by central governments. Seldom, however, do different kinds of explanations engage directly in dialogue over the same cases.

The papers in this special issue are the product of a comparative interdisciplinary workshop on Natural Resources and Violent Ethnic Conflicts in the Asia Pacific Region' held in Honolulu, Hawaii, 18-20 March 2005. 'The workshop brought together scholars who study conflicts between ethnic groups and those who study conflicts over natural resource claims in order to examine the interplay of resources and ethnicity and to seek answers to the question of why violence occurs in some cases and not in others. Workshop organisers identified case studies known to possess both resource and ethnic competition and selected several which had experienced significant violent conflict as a consequence, and several in which violence had been averted or defused. The case studies selected were Papua New Guinea (PNG), West Kalimantan (Indonesia), Aceh (Indonesia), Jharkhand (India) and Northern Thailand. Of these, Jharkhand and Northern Thailand were identified as cases where significant ethnic violence had generally been averted, Papua New Guinea as a case where it had occurred but subsequently been defused, and West Kalimantan and Aceh as cases where conflict had occurred and had not been successfully resolved. As the Aceh papers have been published separately, they are not included in this special issue.

There are many theoretical approaches to the study of both ethnic conflict and resource conflict to choose from. In order to facilitate a meaningful dialogue, we limited the interaction to two relatively coherent 'clusters' of approaches whose contributions to understanding 
these issues have not received sufficient attention in recent years. One cluster is the wellestablished literature on ethnic politics found mainly (though not exclusively) in the comparative politics subfield of political science, which we refer to as 'political ethnology'. Political ethnologists focus on the question, 'Why do ethnic identities become the source of political mobilisation in some cases but not others, or at some points in time and not others?' Their answers tend to focus on competition among rival elites over the character of the state or access to the benefits of modernity, but they see processes of identity group formation as an important intervening variable and view natural resources as providing only one stimulus among many possibilities for such a contest to develop.

The other cluster is 'political ecology', a relatively new literature on environment and society found mainly in geography, anthropology and other social sciences. Political ecology treats ethnic conflict as one of a wide variety of conflicts over resource claims involving multiple, and often times, competing individuals and groups, actors and interests. Political ecologists seek to integrate physical and social science explanations for conflict, emphasise local history while adopting a multiple-scale perspective that pays attention to international policy and markets, and focus attention on both immediate users of land and the role of the state and its ideologies.

It should be emphasised, however, that this special issue is not a debate between 'materialist' and 'culturalist' explanations of ethnic conflict or between 'greed' and 'grievance' based explanations. The two clusters of literature we are interested in can both be distinguished from recent 'political economy' approaches that explain ethnic conflict as a direct consequence of elite efforts to control revenues from resources. They are also both distinct from approaches to 'identity politics' derived from cultural studies, anthropology or other disciplines that see ethnic conflict as arising directly from concerns over cultural identity.

The political economy literature divides resource-based explanations into those focusing on resource abundance - or 'the resource curse' - where economic rents offered by primary commodity exports are seen as generating conflict (de Soysa, 2000; Ross, unpubl. data), and those focusing on resource scarcity - where population growth and resource degradation and scarcity are seen as generating conflict (Homer-Dixon, 1999). A second, parallel though not necessarily identical distinction is the greed/grievance dichotomy focusing on the presumed motives of actors (Collier and Hoeffler, 1998) where the resource curse paradigm is associated with conflicts driven by greed to control abundant resources and resource scarcity is associated with grievances over the degradation and lack of resources.

The idea of conflicts being driven by resource scarcities is strongly associated with the environmental scarcity school linked with HomerDixon (1999), and has come to play a powerful role in the popular imagination. Recent writings in both political science and political ecology (e.g. Reno, 1998; Suliman, 1999; Peluso and Watts, 2001) challenge the link between scarcity and poverty with violence. On the other hand, the resource curse hypothesis, again used in some form or another by many political scientists and political ecologists working on environment and resources, shows that resource abundance and large-scale processes of environmental extraction, rehabilitation or amelioration are associated with violence more often than scarcity per se (Peluso, 1993; Schroeder, 1995; Ross, 1997, 2001; Peluso and Watts, 2001).

Political ethnologists share with the political economists a methodological commitment to explanations that can be generalised across a large number of cases, an emphasis on elite competition as the agent of change and a preference for studying conflict at the 'macro-' level. However, they differ from political economy approaches - and resemble ethnographic ones - in taking state policies towards culture and ethnic identity as an important source of conflict. Conversely, political ecology approaches resemble political economy approaches in their emphasis on natural resources and state policies in this area but, like ethnographic approaches to identity issues, emphasise the importance of local or smallscale studies, validating importance of culture values in generating real grievances around state action (Fig. 1).

While recognising that each of these clusters contains diverse theoretical traditions and the 


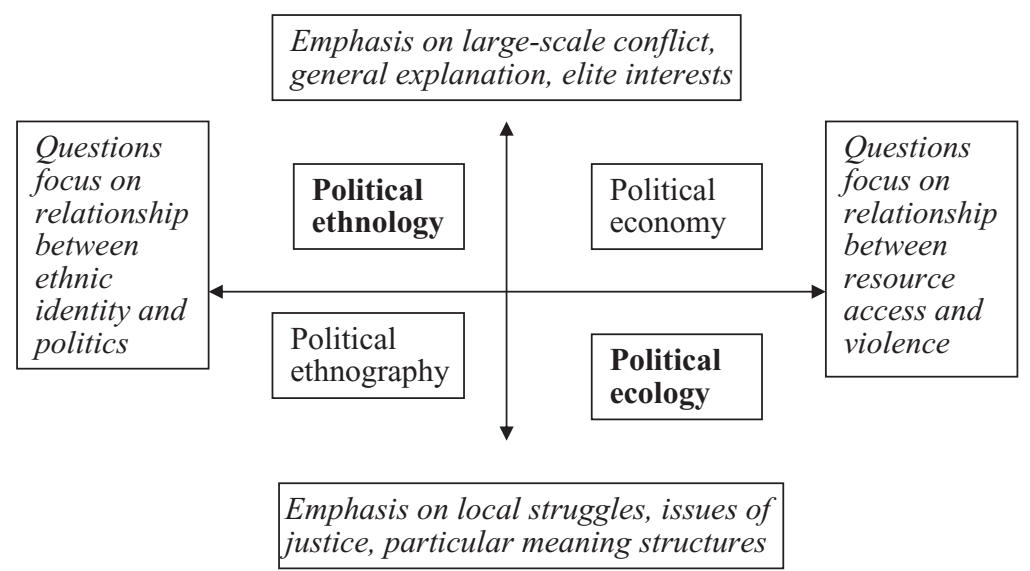

Figure 1. Four tendencies in studying ethnicity, resources and violence

differences among the clusters are not watertight - some authors in each might not even embrace the label we have assigned to them - our hope was to identify certain basic processes that each cluster focused on and through that exercise to engage in a dialogue about the different solutions these literatures might prescribe.

\section{Contrasting theories}

\section{Political ethnology and the study of ethnic conflict}

The study of ethnic conflict has been an important topic in sociology, cultural anthropology and political science since at least the 1950s and arguably earlier, and the work in each discipline has drawn on the others. In political science and sociology, its roots lie in the study of ethnic politics in the United States - in particular urban political machines - as well as in the study of nationalism in Western Europe. The most sustained attention paid to the topic, however, has come from research on nonWestern developing countries during the 1960s and 1970s in the subdisciplines of comparative politics and cultural anthropology.

Political scientists have traditionally focused on ethnic conflicts that involve relatively large groups that contend directly with or over control of the state. They have therefore tended, implicitly, to focus on ethnic groups that are capable of generating claims to being 'nations' or are at least large enough to constitute 'imagined communities' (Anderson, 1983) making claims on central governments on the basis of a (putative) shared politico-cultural identity. Thus, Horowitz limited his mammoth work of synthesis to cases 'that are relatively large and interact at the center of politics rather than in isolated local pockets' (Horowitz, 1985: 16). The principal debates within this cluster are over first, the origins of ethnic identity and, second, why ethnic differences are politicised.

Early approaches in both cultural anthropology and political science reflected the assumptions of modernisation theory that ethnic ties were pre-modern and pre-rational - 'primordial sentiments' in Geertz's (1963) famous words and would fade away as modernisation progressed. The core assumptions were that ethnic identity was inherited; that ethnic conflict stemmed from a sense of threat to the group's identity from other groups or the state, but that modernisation would 'dissolve' these identities as individuals assimilated to the dominant culture. This position, often termed 'primordialism' by its critics, was largely discredited by the growing evidence by the 1970s that assimilation was not happening. It has been replaced by a number of contending schools.

One position retains the core assumptions of the primordialist position outlined above except the belief that ethnic identity dissolves under modernisation. For instance, for Walker Connor (1972) ethnic groups are historically formed nations and conflict results from trying to erase their identity. Anthony Smith (1986), taking a more moderate position, argues that nations have their roots in ethnic groups or 'ethnies' that 
have developed a sense of shared identity over time and that this identity is difficult to erase, but he also notes that not all ethnies become nations. Critics often still term this position 'primordialist' on the grounds that these scholars ground politics in identity, but this may be unfair as there is no implication that the persistence of identity politics is somehow premodern. Smith terms his position 'perennialism' and we will adopt that here.

Even without the evolutionary baggage of pure primordialism, however, perennialism has been a minority view among scholars of ethnic politics in developing countries because research points strongly to two aspects of ethnic politics in these countries that cannot be reconciled with the perennialist view. The first is that many ethnic identities are of relatively recent vintage, frequently the product of colonial policy. The second is that it is quite impossible to predict whether ethnic differences become the basis for political mobilisation - or as political scientists like to say, politically salient or just politicised - on the basis of observable cultural differences or observable oppression. Rather the actions of elites often play a crucial role here.

In recent years these two criticisms of perennialism are often seen as characteristic of distinct approaches to the study of ethnic politics. 'Constructivists' tend to emphasise the creation, invention and contingent aspects of ethnic identities and ideologies. They often work in the post-structuralist tradition and often treat the explanation of identity formation as sufficient to understand why ethnic politics occurs. 'Instrumentalists' like Rabushka and Shepsle (1972) and Bates (1983) on the other hand tend to explain ethnic conflict as the result of elite competition over economic resources, principally control over revenues. Instrumentalists typically work in the rational choice tradition in political science, which draws much of its theoretical framework from economics. Unlike primordialists, instrumentalists treat the occurrence of ethnic conflict as a variable that can be affected through policy. However, like primordialists, many instrumentalists view ethnic groups as fairly coherent entities and frequently treat their existence as a given.

There is however an established tradition of studying ethnic politics that combines the insights of instrumentalism and constructivism, and indeed predates them. Variously described as the 'modernist' (Smith, 1986) or 'elite competition' (Brass, 1985) approach, this school was strongly influenced by work on European nationalism (Deutsch, 1953, 1961). It is most prevalent in the comparative politics subfield of political science but could also include the work of historians such as Hobsbawm (1990), philosophers like Gellner (1983) and others including Anderson (1983). As Brass' term fails to distinguish these scholars from rational choice theorists, we will adopt Smith's term 'modernist'.

Like instrumentalists, these modernist scholars saw economic competition between rival elites, especially in the urban modern sector as the driver of ethnic competition (Young, 1976; Horowitz, 1985). Like primordialists, they view state policies towards cultural markers, such as efforts to promote a common language or official religion under the guise of 'nation-building' as having an important effect on ethnic conflict. And like constructivists, they emphasise the 'invention' of ethnic histories and ethnic identities; indeed, they may be said to have discovered it.

Scholars working in this tradition, however, emphasised the internal divisions among ethnic groups (e.g. Brass, 1985) and paid special attention to the question of why ethnic divisions rather than class or other kinds of differences were politicised in a given setting. Frequently, they emphasised that cultural policies were most important to elites - traditional religious elites or upwardly mobile new literate groups and that it was ethnic entrepreneurs from these strata who engaged in inventing ethnic ideologies and sought to mobilise rural and less privileged members of a group around them.

\section{Political ecology and the study of resource conflict}

Political ecology refers to the social and political conditions surrounding the causes, experiences and management of environmental problems (e.g. Blaikie and Brookfield, 1987; Bryant, 1992; Greenberg and Park, 1994; Zimmerer, 2000). This cluster suggests that the environment is an arena of contested entitlements in which conflicts or claims over property and access to resources (including land), labour and the politics of recognition play themselves 
out (Neumann, 1998; Peluso and Watts, 2001; Schroeder, 2002). Political ecologists have sought to include the influences of international as well as local political economy and geopolitics in their analyses of resource conflict, whether violent or not. In this view, places and people must be situated in order to understand the various expressions of power affecting them and the specific circumstances that precipitate violence. Political ecology provides tools for thinking about the conflicts and struggles engendered by the forms of access to and control over resources.

At least two types of analyses in political ecology can be identified. The first type adopts a largely structuralist explanation of land degradation through reference to the forces of capitalism, or oppressive state policies and their impacts on local people and environment (e.g. Blaikie, 1985; Blaikie and Brookfield, 1987; Bryant and Bailey, 1997). The systems that govern natural resource use, overuse, degradation and recovery of the environment are structured into a larger social engine, which revolves around the control of nature and labour. The second type of analysis is influenced by poststructuralist approaches to social science that focus on the historical and cultural influences on how society understands environmental change and degradation, and the role of linguistics and politics as forces in their own right. The labelling of peasants displaced by the introduction of scientific forestry practices in Java as 'forest thieves', 'forest encroachers', 'squatters' and 'illegal grazers' demonstrates the role of language as a political force for delegitimising customary land claims (e.g. Peluso, 1992; Escobar, 1995, 1996, 1998; Rocheleau, 1995; Leach and Mearns, 1996).

A number of scholars base their explanations of resource violence on James Scott's idea of the moral economy (Scott, 1979). Scott suggested that some forms of extraction from small holders or peasants are acceptable to them (indeed, they are moral subsistence obligations), while other forms are not. When concepts of the moral economy are violated, peasant movements may arise to challenge political and economic authority. Also as market controls over household transactions increase, the moral economy becomes less stable, fomenting possible social upheaval (Scott, 1979).
Other political ecologists have built on Vandergeest and Peluso's (1995: 387) description of how modern states simplify the claims made by individuals and communities to natural resources by 'dividing their territories into political and economic zones, rearrange people and resources within these units, and create regulations delineating how and by whom these areas can be used'. Vandergeest and Peluso suggest that the lack of fit between lived space (space as known by people in their everyday lives) and abstract space (space as mapped and administered by government agencies) contributes to the instability of territorial strategies of modern states and to increasingly violent conflicts between resource users and state agencies that attempt to control those uses.

Many scholars suggest that concepts and constructions of community and identity often propel or suppress conflict (Robbins, 2004). Rural people have often actively or purposely chosen to define their identity in terms of the resources they have traditionally accessed and used. They do this not only because their lives are dependent on these resources, but because it is a pragmatic method of claiming 'ownership' against other groups as well as the state.

Another approach political ecologists have used for understanding environmental conflicts has been to critically examine the so-called 'scientific truths' or 'environmental orthodoxies' about environmental degradation, nature conservation, forest management and other human/ environment issues that are often used to justify measures that harm the interests of small farmers. Many government officials and lay people, for example, believe that logging and deforestation decrease rainfall and stream flow, and increase erosion and floods. These beliefs have led to policies that seek to relocate farmers from watershed zones (often forcibly). Since the 1920s, however, hydrological research has actually suggested that the effects of forests on rainfall are small (see Saberwal, 1998) and that the presence of forests does not increase stream flow and in fact forests consume more water than any other form of vegetation. The purposeful or accidental misunderstanding of what modern science says about a number of environmental issues - shifting cultivation, desertification, tropical deforestation, rangeland degradation - has been the basis of government 
policies that seek to remove people from their land, limit their rights to mange their land and natural resources, and other injustices, and consequently also the basis of social unrest and conflict.

\section{The cases}

The papers by Neil Englehart and Chusak Wittayapak explore why there have not been more sustained challenges to the Thai state's resource policies by minority ethnic groups in Northern Thailand against whose interests these policies discriminate. Englehart, a political scientist, examines the question of why local conflicts do not aggregate into larger, more organised insurrections organised along ethnic lines by focusing on the relationship between the state and ethnic identity. He suggests two factors are key: the mode by which ethnic minority groups were integrated into the new Thai state in the nineteenth century, and the relatively high capacity of that state to deter conflict, bargain with opposition groups and coerce rebels. Ethnic groups were included in the expanding Thai state as elements of their muang rather than as ethnically distinct territories. They thus had few common grievances or even a shared political history around which to unite. Furthermore, the Thai state has been strong enough to either mediate conflicts or intervene decisively on one side. No movement has succeeded in challenging the state's military predominance and police powers. Thus, even in the presence of discrimination and abuse, minority groups have not organised themselves to resist majority Thai power. Instead, they participate in national life employing the symbols and techniques of protest movements across the country, taking care to display their loyalty to the Thai nation even when they are not ethnically Thai. This pattern is in sharp contrast to neighbouring Burma/Myanmar, which has similar ethnic composition and natural resources. There ethnic groups with a strong bond due to shared history under the British and facing a weak postcolonial that was weakened even further as a consequence of the Japanese occupation did launch violent resistance to the central government. That country has endured 60 years of ethnically based civil war, while Northern Thailand has seen very little organised violence.
Chusak Wittayapak looks at resource conflicts and ethnic violence between the lowland Thai and the ethnic highlanders in Northern Thailand from a political ecology perspective. He argues that to understand resource conflict and ethnic violence, we need to look into the historical and geographical construction of ethnic identifications within the process of modern Thai nationstate making. Chusak suggests that ethnic identifications were traditionally reinforced by the construction of history and spatial differentiation and that conflicts today have become even more complicated with issues of class, ideologies, scientific forestry, nationalism and the urban/rural divide. In terms of solutions, Chusak suggests that the democratisation of resource contest and environmental politics seen in the community forest movement has provided some space for negotiation and protest. This has helped to minimise the conflict and violence.

Sarah Jewitt and David Stuligross propose that the Jharkhand movement in northern India, which sought and eventually obtained separation from the state of Bihar, resists classification as stemming either from ethnic competition or from resource grievances and that it has, at different times, mobilised around each set of issues. They note that while sporadic smallscale violence has occurred as a result of these issues, significant violent political mobilisation has been averted.

Jewitt examines the movement from a political ecology perspective and focuses on violence arising from natural resource-related grievances; notably land alienation, forest policy and employment from Jharkhand's mines. Drawing from political ecology's emphasis on the need to examine conflict from a range of different spatial scales, Jewitt emphasises the importance of a micro-political ecology approach (Neumann and Schroeder, 1995) for understanding how locally based conflicts over natural resources harden into more established grievances that can be mobilised politically as part of a wider, and potentially violent protest movement. In terms of solutions to resource-related conflict, Jewitt again emphasises the need to focus on different spatial scales. At the grassroots level, she argues that micro-political ecology approaches are valuable for identifying where individual or 
community-based resource management (and income generating) initiatives are most likely to succeed in addressing or heading off locally based resource conflicts, thus helping to prevent them from hardening into more serious grievances and violent conflict. At the regional and national level, meanwhile, she highlights a range of policy initiatives that have potential for addressing long-standing grievances over land alienation and forest use, but emphasises the need for greater stability and political will on behalf of the Jharkhand State and central governments for such measures to succeed.

Stuligross, a political scientist, highlights the challenges both governments and potential grassroots leaders face when they try to understand what constitutes 'social justice' on resource definition and distribution issues that arise simultaneously. He argues that democracy and demography combine to make social justice difficult to achieve through state and national political institutions. In terms of solutions, he suggests that institutional designs that provide plausible access to individuals defined along any of an array of sectoral or cultural criteria can be, and have been, remarkably effective at providing sufficient optimism in the political system to forestall violence while more substantively meaningful accommodations are worked out. For example, the constitutional guarantees of affirmative action in jobs, educational institutions and electoral representation for upwardly mobile 'tribal' groups helped to co-opt crucial elements of minority ethnic groups and avoided anything resembling a tribal insurgency.

The papers by Benjamin Reilly and Glenn Banks discuss the origins and nature of the frequent conflicts that surround resource operations and elections in Papua New Guinea. With the exception of the erstwhile separatist movement in Bougainville, these conflicts have tended to be relatively low level. Reilly, a political scientist, emphasises the crucial role that electoral systems have played in stimulating or forestalling ethnic violence at election time. While he suggests that the extreme ethnic diversity in Papua New Guinea has had the effect of diffusing ethnic tensions, he also shows that this is more likely to occur when electoral mechanisms encourage candidates to solicit votes among ethnic groups other than their own. Thus, the use of an alternate vote system, gave 'a centripetal spin to the political system to pull the parties towards moderate, compromising policies', while the shift to a winner takes all electoral system encouraged candidates to appeal to their own ethnic groups and use violence to depress turnout among others.

Banks, a political ecologist, suggests that while conflicts in Papua New Guinea have always been driven by disputes over resources, they are better understood as conflicts around identity rather than resources. Working at local and regional scales, Banks sees conflicts in PNG as really being about 'local understanding of belonging and identity which become the sites of contestations'. It is belonging to a place, a piece of land and its associated resources, which gives a people its sense of identity. Banks argues that intervening in resource conflicts requires a long-term perspective, an orientation towards process rather than outcomes and a commitment to the various parties - effectively a move beyond a passive neutrality to becoming an 'interested' party.

Nancy Peluso and Gerry van Klinken examine the violence perpetrated by Dayaks against Madurese in West Kalimantan, Indonesia, in the 1990s. The papers are remarkably different - indeed one conference participant commented that it seemed that authors had visited different West Kalimantans. Differences exist in theory, circumstances under which the studies were conducted, scales of analyses geographically, politically and historically, as well as the resources in question. While the stories told by the two authors are poles apart, there are ways in which the two papers may be closer than evident at first glance. Both authors agree that ethnic militancy is in some sense a product of state actions. Peluso, a political ecologist, argues that the military violence and militarised contexts inhabited by Sambas Dayaks since the 1960s, and the very practices and tactics of the military, cascaded into the forms, patterns and practices of violence against the Madurese in 1996-1997.

Van Klinken, a political scientist, examining two episodes of anti-Madurese violence, the second involving Malays, suggests the stimulus for the violence was provided by the devolution of authority to elected local governments which gave both Dayak and Malay leaders an 
incentive to carry out 'ethnic cleansing' in their areas. In his view, after the 1996-1997 Dayak attacks on Madurese, both Dayak and Malay leaders 'learned' that violence could have the effect of selective evictions and a form of ethnic cleansing.

In terms of solutions, Peluso recommends greater participation and more explicit inclusion of Dayaks in various arenas of government and the economy, to in part make up for the long period of exclusion. Van Klinken recommends building an effective and democratic state. But neither author really has concrete suggestions for ways of bringing Madurese back into the rural areas of the province and guaranteeing their safety. Promises to that effect were made after 1997, but they were tragically and troublingly broken.

\section{Principal findings}

The principal findings of this special issue fall into two broad categories. The first concerns how the two approaches differ in their analysis of the origins of violence in areas where both resource and ethnicity are in contention. The second concerns policy prescriptions flowing from these analyses. It is important to note that neither research cluster is as homogeneous as expected, especially as regards giving priority to resource-based and non-resource-based explanations. However, amid the differences certain recurring themes were identified.

\section{Explanations}

Both political ethnology and political ecology agree that ethnic and resource grievances occur not so much out of objective deprivation but out of relative deprivation when groups compare their situation with others, with the past, or with future expectations. Political ethnology suggests that economic competition between rival elites, especially in the urban modern sector, provides a driver of ethnic competition. This, however, leaves open the question of why less privileged segments should follow the lead of insurgent elites, especially those, like upwardly mobile middle-class groups, who have no traditional hold on the rural population. Political ecologists suggest that competing claims to resources between the state and ethnic groups or among multiple groups can provide grievances which are sufficient to mobilise rural-based groups to action. This suggests an area where political ecology and political ethnology can learn from one another.

Political ethnology - at least of the modernist variety - suggests that both the state's need to homogenise culture within its territory (including the roles of the printing process and perhaps other mass media), and the role culture plays in mediating opportunity and upward mobility provide the context within which cultural conflict occurs. Political ethnology argues that resentments over cultural policies will be most marked among individuals seeking entry into modern occupations and focused on those aspects of cultural policy that affect their prospects. More generally, individuals competing to enter the modern sector have been discovered to be more likely to find cultural differences salient enough to mobilise politically around them.

Political ecologists, on the other hand, argue that the driving political action is territorialisation (Vandergeest and Peluso, 1995) and that it is the need of the modern state to simplify (or homogenise) the landscape into overlapping political and economic zones, to arrange people and resources within these units, and to create regulations delineating how and by whom these areas can be used that provides a major context within which resource conflicts occur. The overlap between the homogenisation of culture and territory suggests that political ethnologists and political ecologists share similar perspectives with respect to the impact of the modern state and its need to simplify the environment within which it operates on different groups of people - urban and rural.

\section{Solutions}

Following the emphasis on elite behaviour, prescriptions for managing ethnic conflict in political science typically focus on co-opting elites. They may include the use of patronage to buy support of individual leaders, substantive policy concessions on cultural issues that enhance upward mobility (such as adopting a neutral official language) and structural changes to the ways in which political power is gained and exercised. Several scholars of ethnic politics have distinguished between two kinds of struc- 
tural changes - the 'power-sharing' variety and the 'integrationist' variety (Horowitz, 1985; Sisk, 1996²). The power-sharing solution, which includes both ethnic federalism and what Lijphart (1977) termed 'Consociationalism' (arrangements assuring ethnic groups participation in the central government), consists of granting ethnic groups as corporate entities a guaranteed share in power in the hopes of encouraging bargaining and compromise among group leaders. This kind of approach is criticised for 'freezing' ethnic identities. It also potentially requires expanding the resources available for division in order to avoid a zerosum contest among ethnic groups and therefore may not be compatible with a focus on sustainable development. The 'integrationist' solutions, those that seek to foster cross-ethnic political allegiances, may be easier to reconcile with measures aimed at fostering effective resource management.

The solutions identified by the political scientists in this special issues both support and vary from those suggested in the previous paragraph for co-opting elites. In the studies where violence had been largely avoided, the common solution was the development of institutions that encouraged elites to develop working partnerships with members of other ethnic groups. Reilly's analysis of Papua New Guinea documented the importance of electoral mechanisms that compel elites to build coalitions across groups. Stuligross' treatment of Jharkhand, where such coalitions had to be forged to obtain a new state, proposed a similar logic. In Thailand, Englehart argues that one of the reasons that ethnic violence has been minimal in Northern Thailand is because the Thai state in the nineteenth century discouraged the development of ethnically distinct territories. In West Kalimantan, the case study where ethnic violence has not been resolved, van Klinken suggests that the establishment of Dayakdominated districts with Dayak district chiefs was a practical means to stop violence in the short term. van Klinken worries, however, that by co-opting and entrenching these leaders in power, the state rewarded the very people and thinking that caused the problem in the first place.

In general, the solutions offered by political ecologists for resolving conflicts address issues of resource access, distribution, perceptions of environmental issues and democratisation of resource management regimes. To resolve resource access conflicts, many political ecologists have promoted decentralised, community-based natural resource management approaches. These approaches seek to empower local governments and users to claim control over the natural resources in their domain. Political ecologists also seek to reduce resource conflicts by promoting a better understanding of the biogeophysical processes that govern or constrain the environment. What new science says about resource-use practices and environmental degradation, however, has frequently failed to lead to new policies, and this has inspired questions about the need for policy to be more deliberative, inclusive and participatory (Blaikie and Muldavin, 2004). Political ecologists argue that resource management policies are political decisions that affect the lives of local people through both the resources they use to support their livelihoods and the ways in which they construct their identities through their relationships with the landscape and each other.

The solutions identified by the political ecologists in this special issue focus on redressing fundamental issues - rights, resource control and decision-making. Jewitt suggests that community-based resource management provided one paradigm for addressing resource access issues in Jharkhand. Political ecologists also seek to reduce resource conflicts by promoting a better understanding of the biogeophysical processes that govern or constrain the environment. Chusak argues that in Thailand a better understanding of the causes of environmental degradation has not led to new policy and that upland farmers are still falsely accused of causing downstream degradation. This disconnection between science and policy inspires political ecologists to suggest that the political and discursive styles of policy-makers need to be more inclusive and participatory. In Papua New Guinea, Banks suggests that conflicts which have their foundation in social inequities or inequalities attenuated by resource developments require solutions that focus on redressing fundamental issues - rights, resource control and decision-making. Peluso echoes these sentiments and recommends that the solution to 
ethnic conflict in West Kalimantan will require greater participation and more explicit inclusion of Dayaks in various arenas of government and the economy, to in part make up for the long period of exclusion.

Both the political scientists and political ecologists stressed the role of democratic processes in alleviating resource competition and ethnic conflicts, but they did this in different ways. The political scientists examined how democracy is structured at national and provincial levels and its consequences in terms of minimising or provoking conflict - or as Reilly writes, 'to pull the parties towards moderate, compromising policies and to discover and reinforce the centre of a deeply divided political spectrum'. The political ecologists were concerned with how democratic institutions were structured at the local level to allow local people to vocalise resource grievances and for identifying and implementing locally acceptable methods for addressing these issues. Wittayapak goes so far as to suggest that the community forest movement in Thailand is not only a struggle for control of forest resources but also increasingly a struggle by local and ethnic communities for the right to govern themselves. Community-based resource management is evolving from a contest for gaining access and control over material resources to a contest for self-determination by local people in the periphery.

In summary, the perspectives and solutions offered by political scientists and political ecologists are not in conflict with each other, but rather add to each other to provide a more comprehensive picture of ethnicity, resources and politics. In totality, the case studies from these disciplines, which we have placed in opposition to each other, do not tell different stories, or suggest mutually exclusive solutions, but rather sum to a deeper, more contextualised understanding of the cause of conflict, and to mutually reinforcing solutions for resolving conflicts.

\section{Notes}

1 The workshop was funded by the United States Institute of Peace Grant \#USIP-329-03F.

2 Note that Sisk (1996) uses 'consociational' to include federal solutions and uses 'power-sharing' to include 'integrationist' approaches. We prefer to distinguish consociational from federal approaches.

\section{References}

Anderson, B. (1983) Imagined communities: Reflections on the origin and spread of nationalism. London: Verso Edition.

Bates, R. (1983) Modernization, ethnic competition and the rationality of politics in contemporary Africa, in D. Rothchild and V.A. Olorunsola (eds.), State versus ethnic claims: African policy dilemmas, pp. 152-171. Boulder, Colorado: Westview Press.

Blaikie, P. (1985) The political economy of soil erosion in developing countries. London: Longman Development Series.

Blaikie, P. and H.C. Brookfield (eds.) (1987) Land degradation and society. London: Methuen.

Blaikie, P. and J. Muldavin (2004) The politics of environmental policy with a Himalayan example. East-West Center AsiaPacific Issues Paper No. 74. Honolulu, HI.

Brass, P.R. (1985) Ethnic groups and the state, in P.R. Brass (ed.), Ethnic groups and the state, pp. 1-56. Totowa, New Jersey: Barnes and Noble Books.

Bryant, R. (1992) Political ecology: An emerging research agenda in third-world studies, Political Geography 11(1): 12-36.

Bryant, R. and S. Bailey (1997) Third-world political ecology. London: Routledge.

Collier, P. and A. Hoeffler (1998) On the economic causes of civil war, Oxford Economic Papers 50(4): 563-573.

Connor, W. (1972) Nation-building or nation-destroying? World Politics 24(April): 319-335.

de Soysa, I. (2000) The resource curse: Are civil wars driven by rapacity or paucity? in M. Berdal and D. Malone (eds.), Green and grievance: Economic agendas in civil war, Boulder, Colorado: Lynne Rienner.

Deutsch, K.W. (1953) Nationalism and social communication. Cambridge, Massachusetts: MIT Press.

Deutsch, K.W. (1961) Social mobilization and political development, American Political Science Review 55(3): 493-514.

Escobar, A. (1996) Constructing nature: Elements for a poststructural political ecology, in R. Peet and M. Watts (eds.), Liberation ecologies: Environment, development, and social movements, pp. 46-68. London: Routledge.

Escobar, A. (1998) Whose knowledge, whose nature? Biodiversity, conservation, and the political ecology of social movements, Journal of Political Ecology 5(1): 53-82.

Escobar, E. (1995) Encountering development: The making and unmaking of the third world. Princeton, New Jersey: Princeton University Press.

Geertz, C. (1963) The integrative revolution: Primordial sentiments and civil politics in new states, in C. Geertz (ed.), Old societies and new states, pp. 105-157. New York: Free Press.

Gellner, E. (1983) Nations and nationalism. Ithaca, New York: Cornell University Press.

Greenberg, J. and T. Park (1994) Political ecology, Journal of Political Ecology 1(1): 1-12.

Hobsbawm, E.J. (1990) Nations and nationalism since 1780: Programme, myth, reality. Cambridge: Cambridge University Press. 
Homer-Dixon, T. (1999) Environment, scarcity and violence. Princeton, New Jersey: Princeton University Press.

Horowitz, D.L. (1985) Ethnic groups in conflict. Berkeley, California: University of California Press.

Leach, M. and R. Mearns (eds.) (1996) The lie of the land: Challenging received wisdom on the African environment. Oxford: James Currey.

Lijphart, A. (1977) Democracy in plural societies: A comparative explanation. New Haven, Connecticut: Yale University Press.

Neumann, R. (1998) Imposing wilderness: Struggles over livelihood and nature preservation in Africa. Los Angeles and Berkeley, California: University of California Press.

Neumann, R.P. and R.A. Schroeder (eds.) (1995) Manifest ecological destinies. Special Issue, Antipode 27.

Peluso, N. (1992) Rich forests, poor people: Resource control and resistance in Java. Berkeley, California: University of California Press.

Peluso, N. (1993) Coercing conservation? The politics of state resource control. Global Environmental Change 3(2): 199-218.

Peluso, N. and M. Watts (eds.) (2001) Violent environments. Ithaca, New York: Cornell University Press.

Rabushka, A. and K.A. Shepsle (1972) Politics in plural societies: A theory of democratic instability. Columbus, Ohio: Merrill.

Reno, W. (1998) Warlord politics and African states. Boulder, Colorado: Lynne Reinner.

Robbins, P. (2004) Political Ecology. Malden, Massachusetts: Blackwell Publishing.

Rocheleau, D. (1995) Maps, numbers, text, and context: Mixing methods in feminist political ecology, Professional Geographer 47(4): 458-466.

Ross, M. (1997) The political economy of boom and bust logging in Indonesia, the Philippines and East Malaysia. pp. 1950-1994. PhD diss., Princeton University.
Ross, M. (2001) Does oil hinder democracy? World Politics 53(4): 325-361.

Saberwal, V. (1998) Science and the desiccationist discourse of the 20th century, Environment and History 4(3): 309-343.

Schroeder, R. (1995) Contradictions along the commodity road to environmental stabilization: Foresting Gambian gardens, Antipode 27(4): 325-342.

Schroeder, R. (2002) Shady practices. Berkeley, California: University of California Press.

Scott, J.C. (1979) The moral economy of the peasant: Rebellion and subsistence in Southeast Asia. New Haven, Connecticut: Yale University Press.

Sisk, T. (1996) Power sharing and international mediation in ethnic conflicts. Washington, DC: U.S. Institute of Peace.

Smith, A.D. (1986) The ethnic origins of nations. Oxford and Cambridge, Massachusetts: Blackwell Publishers.

Suliman, M. (ed.) (1999) Ecology, politics and violent conflict. London: Zed.

USAID (2006) Conflict in the Asia/Near East Region. Retrieved 11 February 2006, from Website: http://www. usaid.gov/our_work/cross-cutting_programs/conflict/ support/ane.html

Vandergeest, P. and N. Peluso (1995) Territorialization and state power in Thailand, Theory and Society 24: 385426.

Young, C. (1976) The politics of cultural pluralism. Madison, Wisconsin: University of Wisconsin Press.

Zimmerer, K. (2000) The reworking of conservation geographies: Nonequilibrium landscape and nature-society hybrids, Annals of the Association of American Geographers 90(2): 356-369. 